\title{
FTY720 and two novel butterfly derivatives exert a general anti-inflammatory potential by reducing immune cell adhesion to endothelial cells through activation of $\mathrm{S1P}_{3}$ and phosphoinositide 3-kinase
}

\author{
Faik Imeri $^{1}$ - Olivier Blanchard ${ }^{1}$ - Aurelio Jenni ${ }^{1} \cdot$ Stephanie Schwalm $^{1,2}$. \\ Christin Wünsche $^{1,2}$ - Aleksandra Zivkovic ${ }^{3}$. Holger Stark ${ }^{3}$. Josef Pfeilschifter ${ }^{2}$. \\ Andrea Huwiler ${ }^{1}$
}

Received: 5 November 2014 / Accepted: 27 July 2015 / Published online: 13 August 2015

(C) Springer-Verlag Berlin Heidelberg 2015

\begin{abstract}
Sphingosine-1-phosphate (S1P) is a key lipid regulator of a variety of cellular responses including cell proliferation and survival, cell migration, and inflammatory reactions. Here, we investigated the effect of S1P receptor activation on immune cell adhesion to endothelial cells under inflammatory conditions. We show that S1P reduces both tumor necrosis factor (TNF)- $\alpha$ - and lipopolysaccharide (LPS)-stimulated adhesion of Jurkat and U937 cells to an endothelial monolayer. The reducing effect of $\mathrm{S} 1 \mathrm{P}$ was reversed by the $\mathrm{S}_{1} \mathrm{P}_{1+3}$ antagonist VPC23019 but not by the $\mathrm{S}_{1} \mathrm{P}_{1}$ antagonist W146. Additionally, knockdown of $\mathrm{S}_{1} \mathrm{P}_{3}$, but not $\mathrm{S}_{1} \mathrm{P}_{1}$, by short hairpin RNA (shRNA) abolished the reducing effect of $\mathrm{S} 1 \mathrm{P}$, suggesting the involvement of $\mathrm{S}_{1} \mathrm{P}_{3}$. A suppression of immune cell adhesion was also seen with the immunomodulatory drug FTY720 and two novel butterfly derivatives ST-968 and ST-1071. On the molecular level, S1P and all FTY720 derivatives reduced the mRNA expression of LPS- and TNF- $\alpha$-induced adhesion molecules including ICAM-1, VCAM-1, E-selectin, and CD44 which
\end{abstract}

Faik Imeri, Olivier Blanchard, and Aurelio Jenni contributed equally.

Andrea Huwiler

huwiler@pki.unibe.ch

1 Institute of Pharmacology, University of Bern, Inselspital, INO-F, CH-3010 Bern, Switzerland

2 Pharmazentrum Frankfurt/ZAFES, Klinikum der Goethe-Universität Frankfurt am Main, Frankfurt am Main, Germany

3 Institute of Pharmaceutical and Medicinal Chemistry, Heinrich Heine-University Düsseldorf, Universitätsstr. 1, 40225 Düsseldorf, Germany was reversed by the PI3K inhibitor LY294002, but not by the MEK inhibitor U0126.

In summary, our data demonstrate a novel molecular mechanism by which S1P, FTY720, and two novel butterfly derivatives acted anti-inflammatory that is by suppressing gene transcription of various endothelial adhesion molecules and thereby preventing adhesion of immune cells to endothelial cells and subsequent extravasation.

Keywords Sphingosine-1-phosphate $\cdot$ Endothelial cells . Immune cell adhesion · FTY720 · ST-968 · ST-1071 · CD44

$\begin{array}{ll}\text { Abbreviations } \\ \text { AMPK } & \text { AMP-activated protein kinase } \\ \text { BSA } & \text { Bovine serum albumin } \\ \text { DMEM } & \text { Dulbecco's modified Eagle's medium } \\ \text { EAE } & \begin{array}{l}\text { Experimental autoimmune-induced } \\ \text { encephalomyelitis }\end{array} \\ & \text { G protein-coupled receptor } \\ \text { GPCR } & \text { Hyaluronic acid } \\ \text { HA } & \text { Intercellular adhesion molecule-1 } \\ \text { ICAM-1 } & \text { Inhibitor of } \text { kB } \alpha \\ \text { IkB } \alpha & \text { Lipopolysaccharide } \\ \text { LPS } & \text { Nuclear factor kB } \\ \text { NFkB } & \text { Phosphate-buffered saline } \\ \text { PBS } & \text { Sphingosine-1-phosphate } \\ \text { S1P } & \text { Sphingosine kinase } \\ \text { SK } & \text { Tumor necrosis factor- } \alpha \\ \text { TNF- } \alpha & \text { Vascular cell adhesion molecule-1 } \\ \text { VCAM-1 } & \end{array}$




\section{Introduction}

In the last years, various sphingolipid species have been appreciated as important bioactive molecules that exert key functions not only as intracellular signaling molecules but also as extracellular ligands to cell surface receptors. Especially, sphingosine-1-phosphate (S1P) has been in the focus of extensive research due to the existence of five different highaffinity S1P receptors denoted $\mathrm{S}_{1} \mathrm{P}_{1-5}$ (Choi et al. 2008; Chun et al. 2002; Mutoh and Chun 2008; Rosen et al. 2013). These receptors are members of the superfamily of $G$ protein-coupled receptors (GPCR) and upon ligand binding couple to a variety of signaling cascades and mediate a multitude of physiological and pathophysiological reactions (Choi et al. 2008; Chun et al. 2002; Mutoh and Chun 2008; Rosen et al. 2013). Since S1P is mainly produced intracellularly by sphingosine kinases (SK) of which two subtypes, SK-1 and SK-2, exist (Alemany et al. 2007), an intracellular site of action of S1P independent of the cell surface receptors was also proposed (Strub et al. 2010). However, the identity of these intracellular targets is still sparsely characterized.

Recently, the immunomodulatory drug FTY720 (fingolimod) has been approved for the treatment of relapsing forms of multiple sclerosis (Kappos et al. 2010). The mode of action includes a phosphorylation step by SK-2 to produce the phosphorylated and active form of the drug (Billich et al. 2003; Zemann et al. 2006). This active form then acts as an unselective agonist at four of the five S1P receptors. Additionally, it acts as a selective functional antagonist at the $\mathrm{S}_{1} \mathrm{P}_{1}$ receptor by downregulating $\mathrm{S}_{1} \mathrm{P}_{1}$. The downregulation of $\mathrm{S}_{1} \mathrm{P}_{1}$ on $\mathrm{T}$ cells leads to a trapping of $\mathrm{T}$ cells in secondary lymphoid organs, and this event is responsible for the immunosuppressive effect of FTY720 (Brinkmann et al. 2002; Matloubian et al. 2004). Besides this effect on T cells, FTY720 has also been proposed to increase endothelial barrier function by a still unclear mechanism (Sanchez et al. 2003; Brinkmann et al.2004).

Immune cell extravasation from the bloodstream to sites of inflammation is a key event in the immune response to infectious pathogens, as well as during sterile inflammatory and autoimmune diseases (Greenwood et al. 2011; Vestweber 2012). The process of leukocyte extravasation from the blood requires a multistep cascade of events between the leukocytes and the endothelium, including initial leukocyte rolling along the endothelium, adhesion to the endothelium, and, finally, transendothelial migration (Greenwood et al. 2011; Engelhardt 2006). Various families of cell adhesion molecules are involved in leukocyte-endothelial cell interactions. These include integrins, intercellular adhesion molecule-1 (ICAM1), vascular cell adhesion molecule-1 (VCAM-1), E-selectin, and other molecules (Kim et al. 2001; von Andrian and Mackay 2000; Worthylake and Burridge 2001). Such endothelial adhesion molecules represent attractive targets for therapeutic treatment of chronic inflammatory diseases and various other diseases, and much effort has been invested to develop drugs that interfere with cell adhesion molecules. These include monoclonal antibodies, peptides, and small molecular molecule inhibitors (Mousa 2008).

In this study, we have investigated whether FTY720 triggers additional molecular reactions than the depletion of peripheral $\mathrm{T}$ lymphocytes that may explain its potent antiinflammatory effect. We show that immune cell adhesion to endothelial cells stimulated under inflammatory conditions is abolished by FTY 720 treatment and that this reducing effect is due to $\mathrm{S}_{1} \mathrm{P}_{3}$ receptor activation. On the molecular level, we show that the reduced adhesion correlates with a reduced expression of the adhesion molecules ICAM-1, VCAM-1, Eselectin, and the hyaluronan receptor CD44. Similar antiinflammatory effects were also seen with two novel butterfly derivatives of FTY720 (Imeri et al. 2014), which, unlike FTY720, are active compounds without the need for prior phosphorylation. Mechanistically, the anti-adhesive effect of FTY720 and its derivatives was dependent on the PI3'-kinase/ Akt pathway but not on the classical MEK/MAPK pathway.

\section{Materials and methods}

\section{Chemicals and materials}

Tumor necrosis factor (TNF)- $\alpha$ was from PeproTech GmbH, Hamburg, Germany; lipopolysaccharide (LPS; E. coli 0111:B4), oligonucleotide primers, LY294002, and U0126 were from Sigma Aldrich, Switzerland; S1P, VPC23019, W146, and JTE-013 were from Avanti Polar Lipids Inc., Alabaster, AL, USA; FTY720 was from Cayman Chemicals Inc., Ann Arbor, MI, USA; Symbiobacterium thermophilum S1P lyase was produced and purified as previously described (Huwiler et al. 2011); and all cell culture nutrients and CellTracker ${ }^{\mathrm{TM}}$ Green BODIPY ${ }^{\mathrm{R}}$ (8-chloromethyl-4,4difluoro-1,3,5,7-tetramethyl-4-bora-3a,4a-diaza- $S$-indacene) were from Invitrogen/Life Technologies, Basel, Switzerland.

\section{Cell culture}

The human endothelial cell line EA.hy 926 was kindly provided by Dr. Edgell (Chapel Hill, NC, USA) (Edgell et al. 1983). Cells were cultivated in Dulbecco's modified Eagle's medium (DMEM) containing $10 \%$ fetal bovine serum (FBS); $10 \mathrm{mM}$ HEPES, pH 7.4; 100 units/ml penicillin; and $100 \mu \mathrm{g} / \mathrm{ml}$ streptomycin. The human monocytic cell line U937 and the adult T cell lymphoma cell line Jurkat were cultured in RPMI 1640 medium supplemented with $10 \%$ heat-inactivated fetal bovine serum, 100 units $/ \mathrm{ml}$ penicillin, and $100 \mu \mathrm{g} / \mathrm{ml}$ streptomycin. Prior to stimulation, EA.hy 926 cells were rendered quiescent by incubation for $24 \mathrm{~h}$ in 
serum-free DMEM including $0.1 \mathrm{mg} / \mathrm{ml}$ of fatty acid-free bovine serum albumin (BSA).

\section{Generation of $\mathrm{S}_{1} \mathrm{P}_{1^{-}}$and $\mathrm{S} \mathrm{P}_{\mathbf{3}^{-}}$-knockdown endothelial cells}

For stable gene silencing of $\mathrm{S}_{1} \mathrm{P}_{1}$ and $\mathrm{S}_{1} \mathrm{P}_{3}$, commercially available short hairpin RNA (shRNA) lentiviral transduction particles were used (MISSION ${ }^{\mathrm{R}}$, Sigma Inc.). For each receptor subtype, four different shRNA constructs were tested and those cell lines that showed the strongest downregulation of $\mathrm{S}_{1} \mathrm{P}_{1}$ mRNA (TRCN0000011359; $66 \%$ reduction) and $\mathrm{S}_{1} \mathrm{P}_{3}$ mRNA (TRCN0000356946; $80 \%$ reduction) were further used for experiments. Transduction was performed according to the manufacturer's instructions. For selection, $1 \mu \mathrm{g} / \mathrm{ml} \mathrm{pu}-$ romycin was included in the medium.

\section{Quantitative PCR analysis}

Real-time PCR was performed using SYBR Green ${ }^{\mathrm{R}}$ and a Bio-Rad iQ iCycler Detection System. Primer sequences were as follows: human ICAM-1: forward: C C G G A A G G T G T A T G A A C T G, reverse : TCCATGGTGATCTCTCCTC; human VCAM-1: forward: C C C T T G A C C G G C T G G A GAT T, revers e : CTGGGGGCAACATTGACATAAAGTG; human Eselectin: forward: TGCATGGAGGGTTGTTAATGG, reverse: GGATGAAAGTGATTAAATTGTGCATAG; human CD44: forward: CCGTGATGGCACCCGCTA TG, reverse: GGACTGTCTTCGTCTGGGATGG; and human 18S RNA: forward: CGATTCCGTGGGTGGTGGTG, reverse: CATGCCAGAGTCTCGTTCGTTATC. IQ ${ }^{\mathrm{TM}} 5$ Optical System Software (Version 2.0) was used to analyze real-time and endpoint fluorescence. One microgram of total RNA isolated with TRIZOL $^{\mathrm{R}}$ reagent was used for reverse transcriptase-PCR (First Strand Synthesis Kit, MBI Fermentas, St.-Leon-Rot, Germany); a random hexamer primer was utilized for amplification. The fold induction values were obtained according to the $\Delta \Delta C_{\mathrm{T}}$ method, after normalization to the housekeeping gene $18 \mathrm{~S}$ RNA.

\section{Adhesion assay to endothelial monolayers}

EA.hy 926 cells in 48-well plates were cultured to confluency and then incubated for $16 \mathrm{~h}$ in DMEM containing $0.1 \%$ BSA. $1 \times 10^{6}$ immune cells/ml (either U937 or Jurkat cells) were incubated in RPMI 1640 medium containing $0.1 \%$ BSA and $5 \mu \mathrm{M}$ of fluorescent dye (CellTracker ${ }^{\mathrm{TM}}$ Green BODIPY ${ }^{\mathrm{R}}$ ) for 30 min at $37{ }^{\circ} \mathrm{C}$. Labeled immune cells were then washed twice with DMEM/0.1 \% BSA and resuspended in DMEM $/ 0.1 \%$ BSA containing $1 \%$ FBS. EA.hy 926 cells and labeled immune cells were then separately stimulated for $5 \mathrm{~h}$ as indicated in the figure legends. Stimulated immune cells $\left(10^{5}\right.$ cells per well) were transferred onto the monolayer of EA.hy 926 cells and incubated for further $30 \mathrm{~min}$ at $37^{\circ} \mathrm{C}$ to allow adherence. Thereafter, wells were gently washed three times with phosphate-buffered saline (PBS) to remove non-adherent cells, and the adherent cells were lysed in $300 \mu$ of PBS containing $0.1 \%$ SDS per well. Remaining fluorescence in the wells was measured with a spectrophotofluorometer (Spectra Max M2, Bucher Biotec Inc.) (excitation wavelength at $485 \mathrm{~nm}$, emission wavelength at $535 \mathrm{~nm}$ ).

\section{Statistical analysis}

Statistical analysis was performed by one-way analysis of variance (ANOVA). For multiple comparisons with the same control group, the limit of significance was divided by the number of comparisons according to Bonferroni.

\section{Results}

\section{$\mathrm{S} 1 \mathrm{P}$ receptor activation reduces immune cell adhesion to human endothelial cells}

Immune cell adhesion to endothelial cells is an important step in an inflammatory process. Since FTY 720 has been shown to exert beneficial effects in various inflammatory animal models, we here investigated whether immune cell adhesion to endothelial cells is affected by FTY720 and subsequent S1P receptor signaling.

To this end, two different human immune cell lines were used, the human $\mathrm{T}$ cell lymphoma cell line Jurkat and the human monocytic cell line U937. The cells were exposed to proinflammatory conditions and then fluorescently labeled with a tracer dye and further co-incubated for $30 \mathrm{~min}$ with an activated monolayer of the human endothelial cell line EA.hy 926. The adhesion of immune cells to the endothelium was measured by a fluorescence reader. When both cell types, i.e., immune cells and endothelial cells, were exposed to proinflammatory stimuli, such as LPS or TNF- $\alpha$, enhanced adhesion of Jurkat cells as well as U937 cells to endothelial cells occurred (Fig. 1). In the presence of $1 \mu \mathrm{M}$ S1P, the LPS- and TNF- $\alpha$-stimulated adhesion was markedly reduced, suggesting an anti-adhesive effect of S1P (Fig. 1). This was further confirmed by incubating cells in the presence of a recombinant extracellularly active S1P lyase (Huwiler et al. 2011) which degraded S1P and reverted the anti-adhesive effect of S1P (Fig. 2a). To pinpoint the S1P receptor subtype involved in this effect, various S1P receptor antagonists were tested. In the presence of the $\mathrm{S}_{1} \mathrm{P}_{1}$ antagonist W146 (Sanna et al. 2006; Gonzalez-Cabrera et al. 2008) or the $\mathrm{S}_{1} \mathrm{P}_{2}$ antagonist JTE-013 (Osada et al. 2002), no reverting effect is seen, whereas the dual S1 $\mathrm{P}_{1+3}$ antagonist VPC23019 (Davis et al. 2005) abolished the anti-adhesive effect of S1P (Fig. 2a). These data 


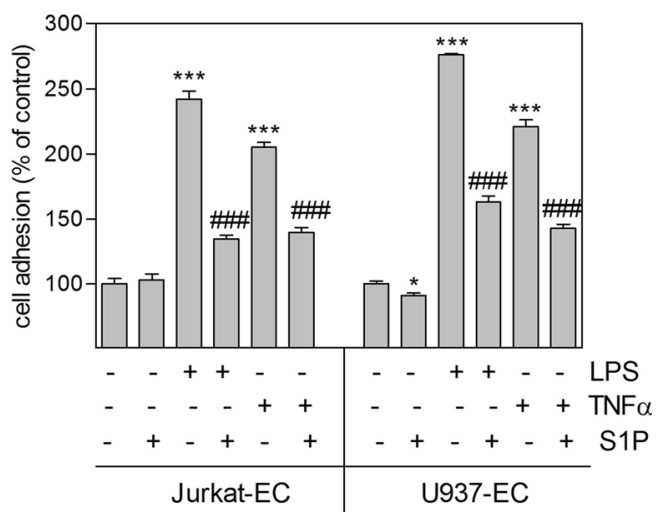

Fig. 1 Effect of S1P on LPS- and TNF- $\alpha$-stimulated adhesion of Jurkat T cells and monocytic U937 cells to EA.hy 926 endothelial cells. Quiescent EA.hy 926 cells were stimulated for $5 \mathrm{~h}$ with either vehicle (Co), LPS $(100 \mathrm{ng} / \mathrm{ml})$, or TNF- $\alpha(0.1 \mathrm{nM})$ in the absence or presence of S1P $(1 \mu \mathrm{M})$. Then, labeled 5-h-LPS-activated Jurkat cells (left side) or labeled 5-h-LPS-activated U937 cells (right side) were added to the EA.hy 926 monolayer and incubated for $30 \mathrm{~min}$. Non-adherent cells were gently washed away and remaining fluorescence on the endothelial monolayer was determined as described in the "Materials and methods" section. Results are expressed as \% of control and are means \pm SD $(n=6-10) .{ }^{*} p<0.05,{ }^{* * *} p<0.001$ considered statistically significant when compared to the unstimulated control values; ${ }^{\# \#} p<0.001$ considered statistically significant when compared to the agonist-stimulated values

suggest that most likely, the $\mathrm{S}_{1} \mathrm{P}_{3}$ receptor is involved in the anti-adhesive effect of S1P. Similarly, when EA.hy 926 cells were used that had a stable knockdown for either the $\mathrm{S}_{1} \mathrm{P}_{1}$ $\left(\mathrm{S}_{1} \mathrm{P}_{1} \mathrm{kd}\right.$ cells) or the $\mathrm{S}_{1} \mathrm{P}_{3}\left(\mathrm{~S}_{1} \mathrm{P}_{3} \mathrm{kd}\right.$ cells $)$, only the $\mathrm{S}_{1} \mathrm{P}_{3} \mathrm{kd}$ cells showed a loss of $\mathrm{S} 1 \mathrm{P}$ protection whereas the $\mathrm{S}_{1} \mathrm{P}_{1} \mathrm{kd}$ cells were still protected by S1P (Fig. 2b).

Since FTY720 is an unselective S1P receptor agonist, activating $\mathrm{S}_{1} \mathrm{P}_{1,3,4}$, and 5 , but not $\mathrm{S}_{1} \mathrm{P}_{2}$ (Brinkmann et al. 2002; Matloubian et al. 2004), we tested its effect on LPS-induced adhesion. FTY720 concentration-dependently reduced LPStriggered adhesion of both immune cell types to endothelial cells (Fig. 3a).

ST-968 and ST-1071 are two novel oxazolo-oxazole derivatives of FTY720, which due to their "butterfly"-like chemical structure are also named butterfly derivatives (Imeri et al. 2014). These compounds were recently shown in vitro to activate the $\mathrm{S}_{1} \mathrm{P}_{1}$ and $\mathrm{S}_{1} \mathrm{P}_{3}$ receptors and in vivo to reduce clinical disease symptoms in a mouse model of experimental autoimmune-induced encephalomyelitis (EAE) (Imeri et al. 2014) in a comparable manner as FTY720. We now tested whether these compounds have a similar effect on immune cell adhesion to endothelial cells as FTY720.

Comparable to FTY720, LPS-stimulated adhesion of Jurkat cells or U937 cells to endothelial cells was concentration-dependently reduced by ST-968 (Fig. 3b) and ST-1071 (Fig. 3c). Similar reducing effects of ST-968 and ST1071 were seen in the adhesion assay when cells were exposed to TNF- $\alpha$ (data not shown).
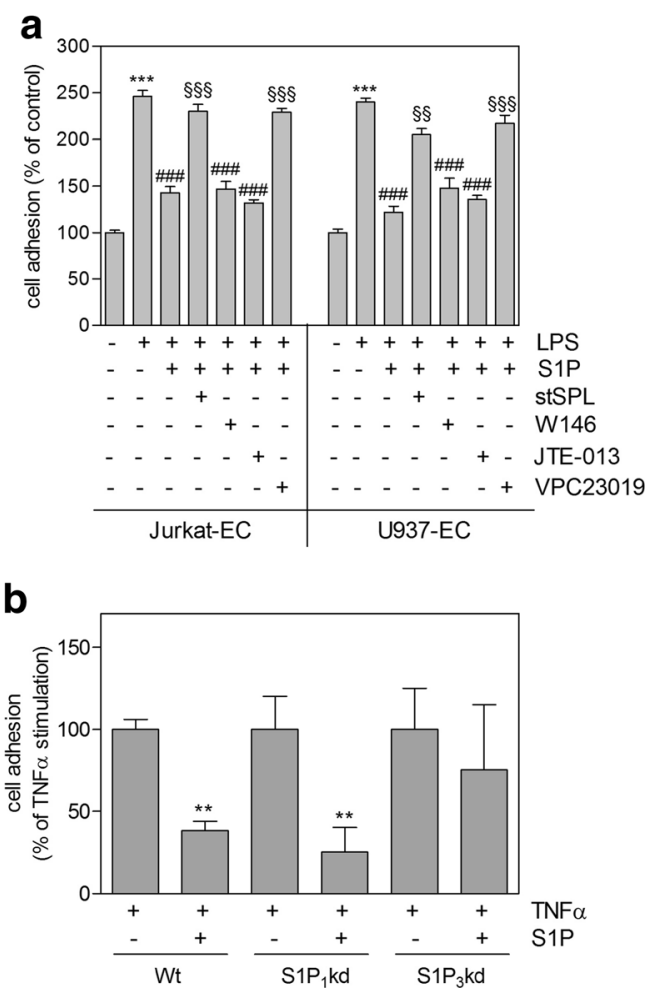

Fig. 2 Effect of recombinant S1P lyase and S1P receptor antagonists on the S1P-mediated reduction of LPS-stimulated immune cell adhesion to EA.hy 926 endothelial cells. a Quiescent EA.hy 926 cells were stimulated for $5 \mathrm{~h}$ with either vehicle $(\mathrm{Co})$ or LPS $(100 \mathrm{ng} / \mathrm{ml})$ in the presence of S1P $(1 \mu \mathrm{M})$ and either recombinant Symbiobacterium thermophilum S1P lyase (stSPL, $10 \mu \mathrm{g} / \mathrm{ml})$, W146 $(10 \mu \mathrm{M})$, JTE-013 $(10 \mu \mathrm{M})$, or VPC23019 $(10 \mu \mathrm{M})$ as indicated. Then, labeled 5-h-LPS-activated Jurkat cells (left side) or labeled 5-h-LPS-activated U937 cells (right side) were added to the EA.hy 926 monolayer and incubated for $30 \mathrm{~min}$. b Control EA.hy 926 cells $(W t), \mathrm{S}_{1} \mathrm{P}_{1}$-knockdown $\left(S 1 P_{1} k d\right)$ cells, or $\mathrm{S} \mathrm{P}_{3}$-knockdown $\left(S 1 P_{3} k d\right)$ cells were treated for $5 \mathrm{~h}$ with either vehicle $(\mathrm{Co}), \mathrm{TNF}-\alpha$, or TNF- $\alpha$ plus S1P. Then, labeled TNF- $\alpha$-activated U937 cells were added to the EA.hy 926 monolayer and incubated for $30 \mathrm{~min}$. Nonadherent cells were gently washed away and remaining fluorescence on the endothelial monolayer was determined as described in the "Materials and methods" section. Results are expressed as \% of control (a) or \% of $\mathrm{TNF} \alpha$ stimulation $(\mathbf{b})$ and are means $\pm \mathrm{SD}(n=6-10) .{ }^{* * *} p<0.001$ considered statistically significant when compared to the respective control values; ${ }^{\# \#} p<0.001$ considered statistically significant when compared to the LPS-stimulated values; ${ }^{\S \S} p<0.01,{ }^{\S \S} p<0.001$ considered statistically significant when compared to the LPS plus S1P-stimulated values

\section{S1P and FTY720 derivatives suppress adhesion molecule expression on endothelial cells}

One molecular event thought to regulate adhesion of immune cells to endothelial cells is the expression of various adhesion molecules including ICAM-1, VCAM-1, E-selectin, and CD44. ICAM-1 and VCAM-1 are well reported to be induced on endothelial cells by proinflammatory stimuli such as TNF- $\alpha$ and LPS and to interact with ligands expressed on activated immune cells (Kim et al. 2001; Lawson and Wolf 

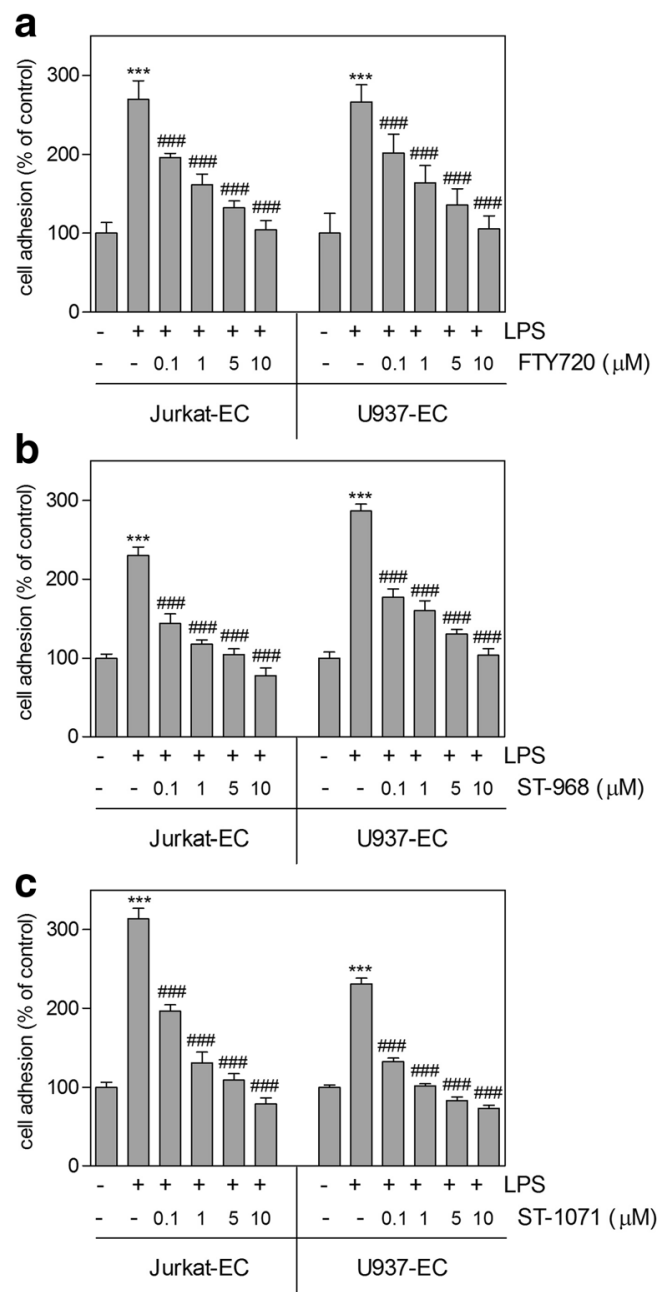

Fig. 3 Dose-dependent effect of FTY720, ST-968, and ST-1071 on LPSstimulated Jurkat and U937 cell adhesion to EA.hy 926 endothelial cells. Quiescent EA.hy 926 cells and CellTracker ${ }^{\mathrm{R}}$-labeled Jurkat cells (left-side columns) or U937 cells (right-side columns) were stimulated separately for $5 \mathrm{~h}$ with either vehicle (-) or LPS $(100 \mathrm{ng} / \mathrm{ml})$ in the absence or presence of FTY720 (a), ST-968 (b), or ST-1071 (c) (in $\mu$ M). Then, both cell types were coincubated for further $30 \mathrm{~min}$ for adherence. Nonadherent cells were then gently washed away and remaining fluorescence on the endothelial monolayer was determined as described in the "Materials and methods" section. Results are expressed as \% of control and are means $\pm \mathrm{SD}(n=6-10) .{ }^{* * *} p<0.001$ considered statistically significant when compared to the vehicle treated control values; \#\# $p<0.001$ considered statistically significant when compared to the LPS-stimulated values

2009). Similarly, CD44 on endothelial cells is known to mediate a rolling interaction with $\mathrm{T}$ lymphocytes under inflammatory conditions (Johnson and Ruffell 2009).

We previously showed that the same herein-used S1P receptor modulators, i.e., S1P, FTY720, ST-968, or ST1071, all downregulated TNF- $\alpha$-stimulated ICAM-1 and VCAM-1 mRNA expression in endothelial cells (Imeri et al. 2014). We now show that also LPS-stimulated upregulations of ICAM-1 and VCAM-1 mRNA were normalized in the presence of S1P, FTY720, ST-968, and ST1071 (Fig. 4a, b). Moreover, E-selectin and CD44 mRNA were also upregulated by both stimuli LPS and TNF- $\alpha$ and normalized by S1P, FTY720, ST-968, and ST-1071 (Fig. 4c-f).

We further addressed the signaling cascade that may mediate the S1P/S1PR-initiated suppressive effect on adhesion molecule expression. In the presence of the PI3-kinase inhibitor LY294002, the suppressive effect of S1P and all FTY720 derivatives on cell adhesion was reverted (Fig. 5) whereas the MEK inhibitor U0126 had no effect (Fig. 5). Similarly, the downregulation of ICAM-1, VCAM-1, E-selectin, and CD44 mRNA expression triggered by S1p and all FTY derivatives was reverted by LY294002 (Fig. 6). These data suggest that S1P and the FTY720 derivatives act via PI3K activation to further suppress adhesion molecule mRNA expressions and cell adhesion.

\section{Discussion}

FTY720 is an approved drug for the treatment of relapsingremitting forms of multiple sclerosis and acts immunomodulatory by inducing $\mathrm{T}$ cell homing and trapping in secondary lymphoid organs. This is mechanistically due to an activation and subsequent downregulation of specifically the $\mathrm{S}_{1} \mathrm{P}_{1}$ receptor on $\mathrm{T}$ cells, which prevents $\mathrm{T}$ cell egress and consequently results in an accumulation of $\mathrm{T}$ cells in secondary lymphoid tissues (Matloubian et al. 2004). Since FTY720 is an unspecific S1P receptor agonist (Brinkmann et al. 2002; Matloubian et al. 2004), and in view of the fact that all cell types express one or several S1P receptor subtypes, it is very obvious that FTY720 must have additional effects on cellular and tissue functions besides the depletion of peripheral T cells.

Previously, it was suggested that FTY720 acts on endothelial cells and enhances endothelial permeability by still unresolved molecular mechanisms (Sanchez et al. 2003; Brinkmann et al. 2004). This mode of action may also contribute, at least partially, to the therapeutic effect in multiple sclerosis. Additionally, animal studies have shown that FTY720 exerts beneficial effects in a number of inflammatory disease models (for review, see Huwiler and Pfeilschifter 2009), and it is tempting to speculate that FTY720 has a more general anti-inflammatory effect and affects local tissueresident cells directly.

In this study, we show for the first time that FTY720 and two novel butterfly derivatives of FTY720, i.e., ST-968 and ST-1071, which do not need to be phosphorylated for activity (Imeri et al. 2014), can reduce immune cell adhesion to endothelial cells in culture and thereby may exert at least parts of their anti-inflammatory effects through this anti-adhesive mechanism. We have identified four endothelial adhesion molecules that likely take part in this anti-adhesive effect as their expression levels were downregulated by S1P, FTY720, and the butterfly derivatives in a similar manner. These 
Fig. 4 Effect of S1P, FTY720, and derivatives on LPS- and TNF- $\alpha$-stimulated mRNA expression of ICAM-1, VCAM1, E-selectin, and CD44 in EA.hy 926 cells. Cells were stimulated for $5 \mathrm{~h}$ with either vehicle $(-)$, LPS $(100 \mathrm{ng} / \mathrm{ml})(\mathbf{a}-\mathbf{d})$ or TNF- $\alpha$ $(0.1 \mathrm{nM})(\mathbf{e}, \mathbf{f})$ in the absence or presence of S1P, FTY720, ST-968, or ST-1071 (all at $1 \mu \mathrm{M}$ ). Thereafter, RNA was extracted and subjected to quantitative PCR analysis using primers for human ICAM-1 (a), VCAM-1 (b), E-selectin (c, e), and CD44 (d, f). 18S RNA was used as an internal control. The ratio of the expression of the gene of interest and 18S RNA was calculated. Data are expressed as \% of control values and are means $\pm \mathrm{SD}$ $(n=3) . * p<0.05, * * p<0.01$, $* * * p<0.001$ considered statistically significant when compared to the unstimulated control values; ${ }^{*} p<0.05$, ${ }^{\#} p<0.01$ when compared to the LPS- or TNF- $\alpha$-stimulated values, respectively a
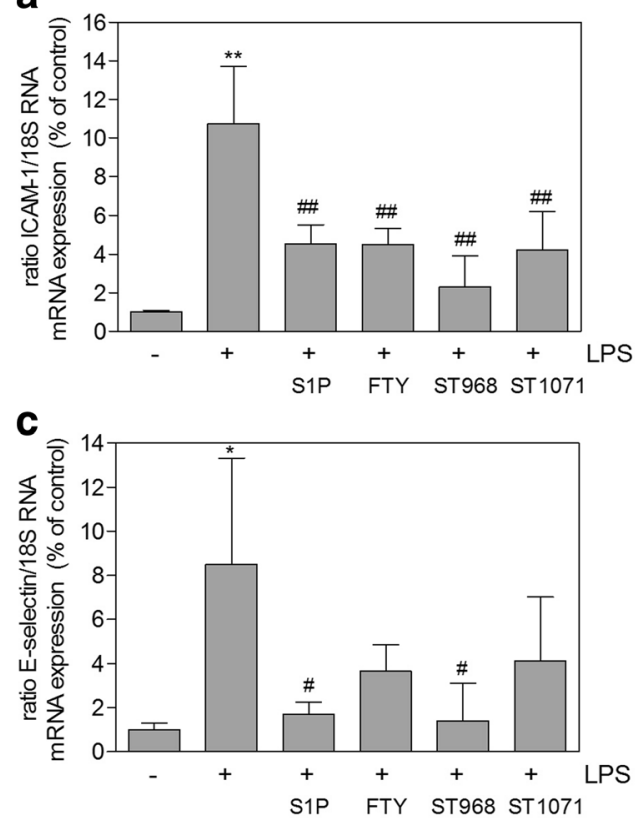

e

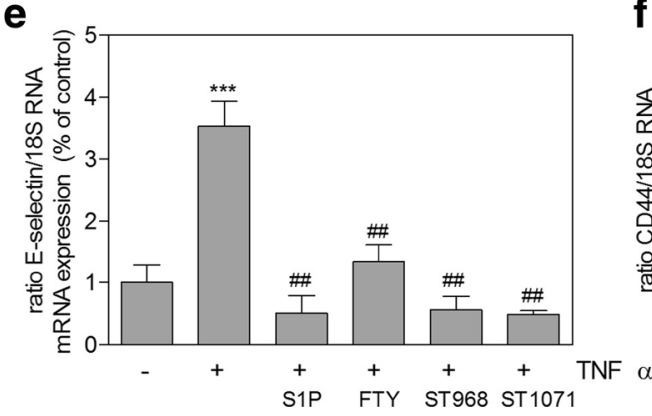

b

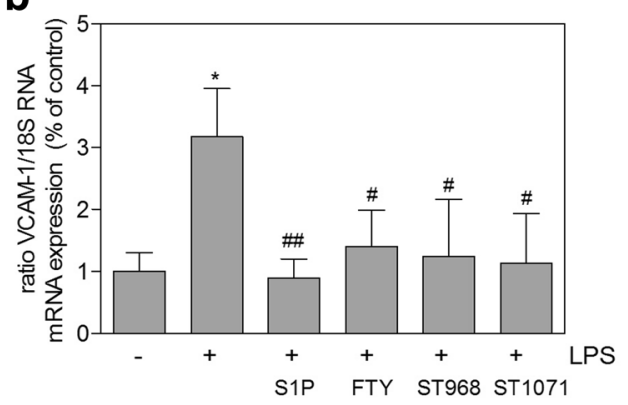

d

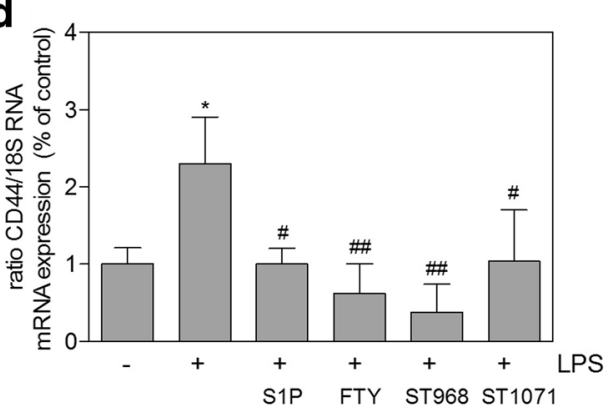

$\mathbf{f}$

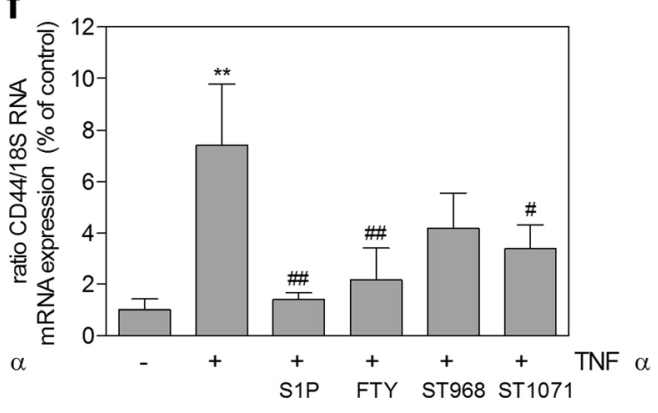

adhesion molecules include ICAM-1, VCAM-1, E-selectin, and CD44.

The important role of ICAM-1 and VCAM-1 in leukocyte adhesion and transmigration is well described (Turowski et al. 2005; Müller 2011). These molecules are known to be induced by proinflammatory stimuli like TNF- $\alpha$ and LPS (Cook-Mills and Deem 2005). Importantly, Foster et al. (2009) reported that in an in vivo EAE model in rats, FTY720 treatment not only reduced disease symptoms but also reduced ICAM-1 and VCAM-1 mRNA expressions in the brain and spinal cord of EAE animals, clearly suggesting reduced immune cell adhesion to the BBB upon FTY720 treatment in vivo. Similarly, we recently showed that ST-968 and ST-1071 also reduce disease symptoms of EAE in mice and in parallel reduced the expression of ICAM-1 and VCAM-1 in the brain and spinal cord (Imeri et al. 2014).

Regarding the molecular mechanism by which S1P and the FTY720 derivatives reduce the expression of adhesion molecules in this study, the $\mathrm{S}_{1} \mathrm{P}_{3}$ receptor is the most likely S1P receptor subtype involved. This became evident by using various receptor antagonists and $\mathrm{S}_{1} \mathrm{P}_{3} \mathrm{kd}$ cells. Neither the selective $\mathrm{S}_{1} \mathrm{P}_{1}$ antagonist nor the $\mathrm{S}_{1} \mathrm{P}_{2}$ antagonist had an effect on the anti-adhesive action of S1P. Only the dual $\mathrm{S} \mathrm{P}_{1+3}$ antagonist VPC23019 reversed the anti-adhesive effect of S1P. Although for all these pharmacological compounds unspecific effects have been reported, the combined pattern of action, together with the data obtained from the $\mathrm{S}_{1} \mathrm{P}_{1} \mathrm{kd}$ and $\mathrm{S}_{1} \mathrm{P}_{3} \mathrm{kd}$ cells, strongly argues for the involvement of $\mathrm{S}_{1} \mathrm{P}_{3}$ in the antiadhesive mechanism of S1P. In line with our data, Theilmeier et al. (2006) also showed that S1P protected mouse hearts from ischemia/reperfusion injury in vivo by blocking leukocyte adhesion to the endothelium which was mediated by the $\mathrm{S}_{1} \mathrm{P}_{3}$ receptor since in $\mathrm{S}_{1} \mathrm{P}_{3}$-knockout mice, no protection by S1P was observed anymore. Whereas these studies suggest the involvement of $\mathrm{S}_{1} \mathrm{P}_{3}$ in the anti-adhesive mechanism, Bolick et al. (2005) rather proposed the involvement of S1P in preventing monocyte adhesion to the endothelium in vivo. These authors used the S1P $\mathrm{P}_{1}$ agonist SEW2871 to show an anti-adhesive effect. Notably, SEW2871 was ineffective in our cellular system (data not shown), prompting us to exclude

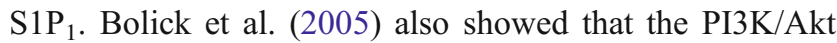
pathway was mechanistically involved. The same group later reported that $\mathrm{S}_{1} \mathrm{P}_{1}$ may also be responsible for an antiinflammatory effect of S1P in diabetic mice (Whetzel et al. 


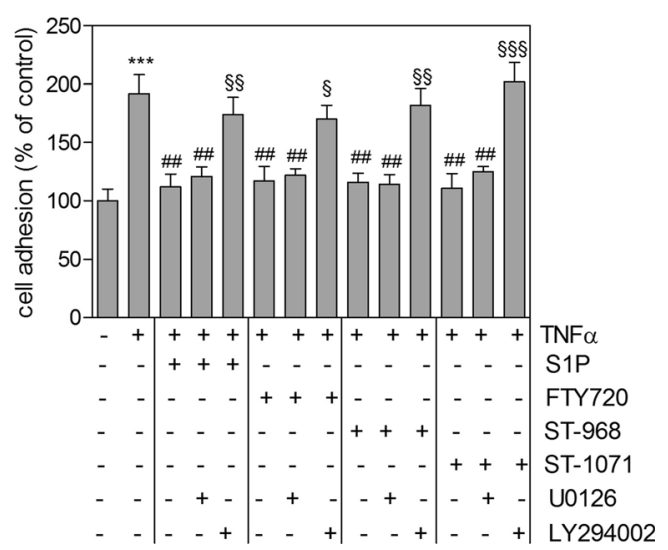

Fig. 5 Effect of MEK and PI3K inhibitors on the anti-adhesive effect of S1P, FTY720 and derivatives on TNF- $\alpha$-stimulated U937 cell adhesion to endothelial cells. EA.hy 926 cells and CellTracker-labeled U937 cells were stimulated separately for $5 \mathrm{~h}$ with either vehicle (-) or TNF- $\alpha$ $(0.1 \mathrm{nM})$ in the absence or presence of S1P, FTY720, ST-968, and ST1071 (all at $1 \mu \mathrm{M})$ in the absence or presence of either U0126 $(20 \mu \mathrm{M})$ or LY294002 $(20 \mu \mathrm{M})$. Then, both cell types were coincubated for further $30 \mathrm{~min}$ for adherence. Non-adherent cells were then gently washed away and remaining fluorescence on the endothelial monolayer was determined as described in the "Materials and methods" section. Results are expressed as $\%$ of control and are means $\pm \operatorname{SD}(n=4-8)$. ${ }^{* * *} p<0.001$ considered statistically significant when compared to the unstimulated control values; ${ }^{\# \#} p<0.01$ considered statistically significant when compared to the TNF- $\alpha$-stimulated values; ${ }^{\S} p<0.05,{ }^{\S \S}{ }_{p}<0.01,{ }^{\S \S} p<0.001$ considered statistically significant when compared to the LPS plus S1P receptor agonist-stimulated values

2006). This may involve $\mathrm{S}_{1} \mathrm{P}_{1}$-mediated inhibition of $\mathrm{NFKB}$ activation in ex vivo-isolated diabetic aortic endothelium (Whetzel et al. 2006).

Regarding the anti-adhesive effect of S1P, Awojoodu et al. (2013) showed a similar phenomenon in vivo without specifically addressing the S1P receptor subtype involved. By surgical transplantation of either S1P- or FTY720-loaded films onto remodeling vessels of inflamed and ischemic tissue in mice, they observed a reduction of inflammatory cell adhesion to the local endothelium. However, the same group also showed that S1P released in microparticles of red blood cells of sickle cell disease patients promotes monocyte adhesion to endothelial cells, suggesting a rather proinflammatory role of red blood cell-derived S1P (Awojoodu et al. 2014). Moreover, the group of Garcia-Rodriguez recently reported that S1P enhanced the LPS/TLR4-triggered adhesion of PBMCs to endothelial cells in vitro (Fernández-Pisonero et al. 2012), whereas they also demonstrated an inhibitory effect of S1P on TLR2induced proinflammatory gene transcription in monocytes (Dueñas et al. 2008).

The agonistic action of FTY720 on $\mathrm{S} \mathrm{P}_{3}$ has been proposed to contribute to some of the side effects associated with FTY720 treatment. In this view, $\mathrm{S}_{1} \mathrm{P}_{3}$, which is highly expressed on cardiac myocytes and perivascular smooth muscle cells, was suggested to be the crucial receptor involved in sinus bradycardia and hypertension seen in mice and rats treated with the FTY720 or related analogs (Sanna et al. 2004; Forrest et al. 2004). On the other side, by using the unselective agonist FTY720 and a novel more selective $\mathrm{S}_{1} \mathrm{P}_{1+5}$ agonist $\mathrm{BAF} 312$ in rats, Fryer et al. (2012) showed rather the $\mathrm{S}_{1} \mathrm{P}_{1}$ mediates bradycardia while hypertension is mediated by the $\mathrm{S}_{1} \mathrm{P}_{3}$. Also, it was reported by Tölle et al. (2005) that FTY720 induced arterial vasodilation in mice through $\mathrm{S}_{1} \mathrm{P}_{3}$ activation on the endothelium leading to eNOS stimulation and subsequent nitric oxide synthesis. From all these studies, which include some controverse findings, it may also be possible that species- and cell type-specific functions of the different S1P receptor subtypes exist. Moreover, by using a selective agonist and shRNA for receptor downregulation, van Doorn et al. (2012) reported that especially the $\mathrm{S}_{1} \mathrm{P}_{5}$ subtype is involved in the maintenance of barrier integrity of brain microcapillary endothelial cells and may also contribute to the immune quiescence state of the BBB. These authors showed that downregulation of $\mathrm{S}_{1} \mathrm{P}_{5}$ strongly upregulated mRNA expression levels of the proinflammatory cytokines and chemokines IL-1 and IL-8, TNF- $\alpha$, and MCP-1; the adhesion molecules ICAM-1 and VCAM-1; as well as the protein ex-

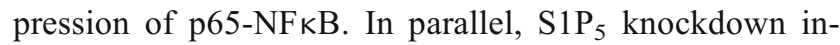
creased monocyte adhesion to cerebral microcapillary endothelial cells in vitro (van Doorn et al. 2012).

Altogether, various $\mathrm{S} 1 \mathrm{P}$ receptor subtypes, i.e., $\mathrm{S}_{1} \mathrm{P}_{1,3}$, and 5 , have been proposed to mediate protective effects on endothelial function. Although evidence is still sparse, it may even be considered that the different S1P receptor subtypes cooperate and cross-regulate each other such as it has been observed for the S1PR/EGF receptor (Kim et al. 2000), S1PR/PDGF receptor (Waters et al. 2003; Pyne et al. 2003), S1PR/purinoceptors (Xin et al. 2004a), and S1PR/TLR receptors (Dueñas et al. 2008; Fernández-Pisonero et al. 2012).

In mechanistic terms, our data suggest that a transcriptional effect is involved in the anti-adhesive effect of S1P, which depends on the PI3-kinase/Akt pathway but is independent of the classical MAPK pathway. This became evident since the PI3K inhibitor LY294002 abolished the protective effect of all compounds not only on immune cell adhesion but also on adhesion molecule expression. In this view, it is worth noting that $\mathrm{S} 1 \mathrm{P}$ receptor signaling, induced by either S1P or FTY720, is known to activate the PI3K/Akt pathway in many cell types including endothelial cells (Igarashi et al. 2001; Xin et al. 2004b, 2006; Bolick et al. 2005).

Our study further demonstrates that the endothelial CD44 adhesion molecule is regulated by $\mathrm{S} 1 \mathrm{P}$ and the synthetic immunomodulatory compound FTY720 or two novel butterfly derivatives of FTY720, i.e., ST-968 and ST-1071. CD44 is a receptor for hyaluronan (HA) and is known to bind and tether HA on the endothelial surface. 
a
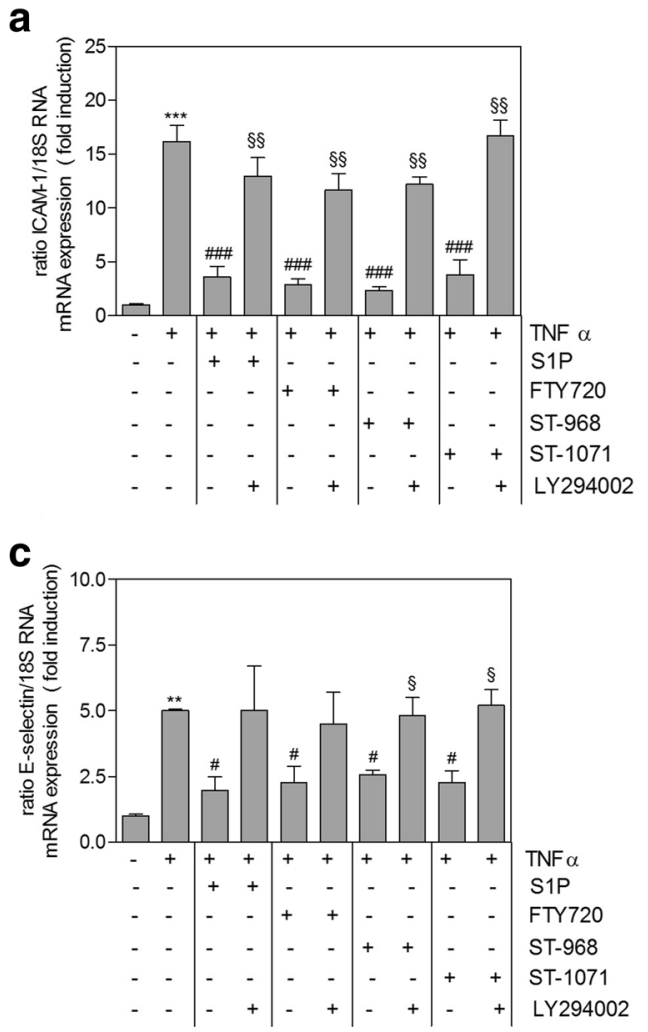

Fig. 6 Effect of the PI3K inhibitor LY294002 on S1P- and FTY derivative-mediated reduction of TNF- $\alpha$-stimulated mRNA expression of adhesion molecules. Cells were stimulated for $5 \mathrm{~h}$ with either vehicle $(-)$ or TNF- $\alpha(0.1 \mathrm{nM})$ in the absence or presence of S1P, FTY720, ST968 , or ST-1071 (all at $1 \mu \mathrm{M}$ ) in the absence or presence of LY294002 $(20 \mu \mathrm{M})$ as indicated. Thereafter, RNA was extracted and subjected to quantitative PCR analysis using primers for human ICAM-1 (a), VCAM1 (b), E-selectin (c), and CD44 (d). 18S RNA was used as an internal

CD44 and HA have been suggested to be involved in the regulation of cell-cell adhesion, proliferation, migration, and differentiation (Ponta et al. 2003).

Recently, it was shown that HA bound to CD44 on central nervous system vascular endothelial cells promotes extravasation of activated T cells during EAE (Winkler et al. 2012). Consequently, blocking antibodies against CD44 were shown to delay the onset of EAE and decrease disease severity (Brocke et al. 1999). These data reflect the important role of CD44 on endothelial cells for leukocyte extravasation and fit well to our findings in endothelial cell cultures where downregulation of CD44 by S1P receptor modulators correlates with reduced immune cell adhesion.

Altogether, this study clearly demonstrates that S1P and FTY720 via $\mathrm{S}_{1} \mathrm{P}_{3}$ activation and PI3K signaling downregulate immune cell adhesion to the endothelial layer and thereby may explain the strong anti-inflammatory effect of FTY720 and butterfly derivatives in various inflammatory disease animal models. Especially the novel butterfly derivatives which are no prodrugs like FTY720 and therefore act independent of
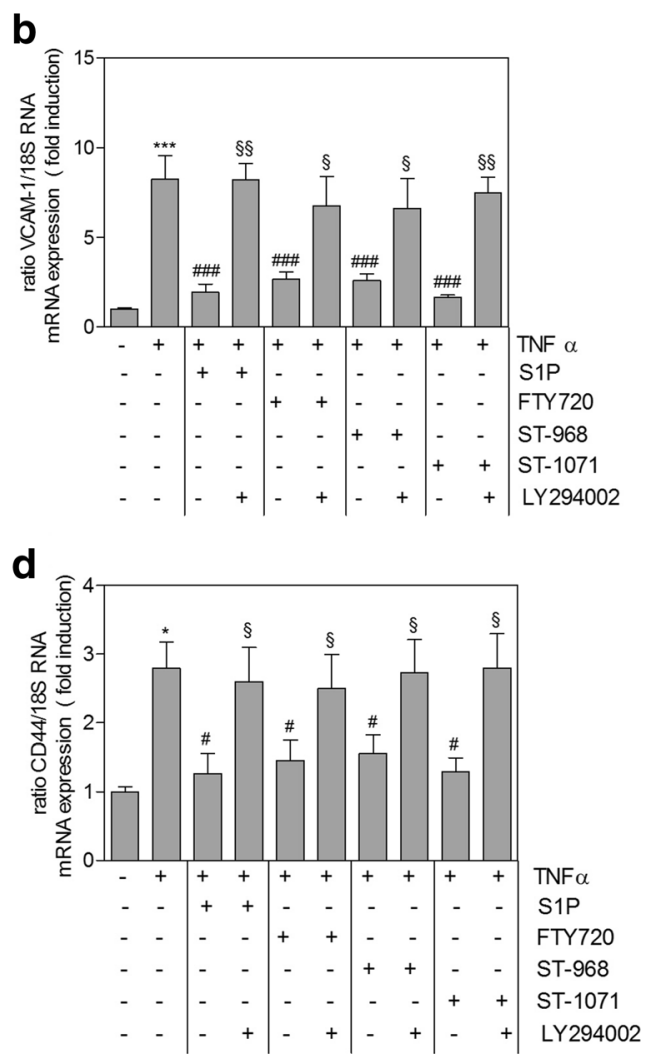

control. The ratio of the expression of the gene of interest and 18S RNA was calculated. Data are expressed as fold induction and are means \pm SD $(n=3) . * p<0.05, * * p<0.01, * * * p<0.001$ considered statistically significant when compared to the unstimulated control values; ${ }^{\#} p<0.05,{ }^{\# \#} p<0.001$ considered statistically significant when compared to the TNF- $\alpha$-stimulated values; ${ }^{\S} p<0.05,{ }^{\S \S} p<0.01$ considered statistically significant when compared to the TNF- $\alpha$ plus S1P receptor agonist-stimulated values

SK-2 activity may be attractive drugs for further development. Their therapeutic use may even be superior to FTY720 for example under conditions where SK-2 is downregulated or inhibited. Notably, SK-2 is considered a possible target for cancer treatment since various studies have shown that a putative SphK2 inhibitor ABC294640 reduced cancer growth in xenograft models (Antoon et al. 2011). Thus, under clinical situations where such inhibitors are given, FTY720 is expected to be inactive whereas the butterfly derivatives may still be fully active.

Acknowledgments This work was supported by the Swiss Society for Multiple Sclerosis, the Swiss National Science Foundation (310030 135619), and the German Research Foundation (SFB 1039 to JP).

Conflict of interest The authors declare that they have no competing interests.

Compliance with ethical standards The manuscript does not contain clinical studies or patient data. 


\section{References}

Alemany R, van Koppen CJ, Danneberg K, Ter Braak M, Meyer Zu Heringdorf D (2007) Regulation and functional roles of sphingosine kinases. Naunyn Schmiedeberg's Arch Pharmacol 374:413-428

Antoon JW, White MD, Slaughter EM, Driver JL, Khalili HS, Elliott S, Smith CD, Burow ME, Beckman BS (2011) Targeting NFkB mediated breast cancer chemoresistance through selective inhibition of sphingosine kinase-2. Cancer Biol Ther 11:678-689

Awojoodu AO, Ogle ME, Sefcik LS, Bowers DT, Martin K, Brayman KL, Lynch KR, Peirce-Cottler SM, Botchwey E (2013) Sphingosine 1-phosphate receptor 3 regulates recruitment of anti-inflammatory monocytes to microvessels during implant arteriogenesis. Proc Natl Acad Sci U S A 110:13785-13790

Billich A, Bornancin F, Dévay P, Mechtcheriakova D, Urtz N, Baumruker T (2003) Phosphorylation of the immunomodulatory drug FTY720 by sphingosine kinases. J Biol Chem 278:47408-47415

Bolick DT, Srinivasan S, Kim KW, Hatley ME, Clemens JJ, Whetzel A, Ferger N, Macdonald TL, Davis MD, Tsao PS, Lynch KR, Hedrick CC (2005) Sphingosine-1-phosphate prevents tumor necrosis factor$\alpha$-mediated monocyte adhesion to aortic endothelium in mice. Arterioscler Thromb Vasc Biol 25:976-981

Brinkmann V, Davis MD, Heise CE, Albert R, Cottens S, Hof R, Bruns C, Prieschl E, Baumruker T, Hiestand P, Foster CA, Zollinger M, Lynch KR (2002) The immune modulator FTY720 targets sphingosine 1-phosphate receptors. J Biol Chem. 277:21453-21457

Brinkmann V, Cyster JG, Hla T (2004) FTY720: sphingosine 1phosphate receptor-1 in the control of lymphocyte egress and endothelial barrier function. Am J Transplant 4:1019-1025

Brocke S, Piercy C, Steinman L, Weissman IL, Veromaa T (1999) Antibodies to CD44 and integrin alpha4, but not L-selectin, prevent central nervous system inflammation and experimental encephalomyelitis by blocking secondary leukocyte recruitment. Proc Natl Acad Sci U S A 96:6896-6901

Choi JW, Lee CW, Chun J (2008) Biological roles of lysophospholipid receptors revealed by genetic null mice: an update. Biochim Biophys Acta 1781:531-539

Chun J, Goetzl EJ, Hla T, Igarashi Y, Lynch KR, Moolenaar W, Pyne S, Tigyi G (2002) International Union of Pharmacology. XXXIV. Lysophospholipid receptor nomenclature. Pharmacol Rev 54:265269

Cook-Mills JM, Deem TL (2005) Active participation of endothelial cells in inflammation. J Leukoc Biol 77:487-495

Davis MD, Clemens JJ, Macdonald TL, Lynch KR (2005) Sphingosine 1phosphate analogs as receptor antagonists. J Biol Chem 280:98339841

Dueñas AI, Aceves M, Fernández-Pisonero I, Gómez C, Orduña A, Crespo MS, García-Rodríguez C (2008) Selective attenuation of Toll-like receptor 2 signalling may explain the atheroprotective effect of sphingosine 1-phosphate. Cardiovasc Res 79:537-544

Edgell CJ, McDonald CC, Graham JB (1983) Permanent cell line expressing human factor VIII-related antigen established by hybridization. Proc Natl Acad Sci U S A 80:3734-3737

Engelhardt B (2006) Molecular mechanisms involved in T cell migration across the blood-brain barrier. J Neural Transm 113:477-485

Fernández-Pisonero I, Dueñas AI, Barreiro O, Montero O, SánchezMadrid F, García-Rodríguez C (2012) Lipopolysaccharide and sphingosine-1-phosphate cooperate to induce inflammatory molecules and leukocyte adhesion in endothelial cells. J Immunol 189: 5402-5410

Foster CA, Mechtcheriakova D, Storch MK, Balatoni B, Howard LM, Bornancin F, Wlachos A, Sobanov J, Kinnunen A, Baumruker T (2009) FTY720 rescue therapy in the dark agouti rat model of experimental autoimmune encephalomyelitis: expression of central nervous system genes and reversal of blood-brain-barrier damage. Brain Pathol 19:254-266

Forrest M, Sun SY, Hajdu R, Bergstrom J, Card D, Doherty G, Hale J, Keohane C, Meyers C, Milligan J, Mills S, Nomura N, Rosen H, Rosenbach M, Shei GJ, Singer II, Tian M, West S, White V, Xie J, Proia RL, Mandala S (2004) Immune cell regulation and cardiovascular effects of sphingosine 1-phosphate receptor agonists in rodents are mediated via distinct receptor subtypes. J Pharmacol Exp Ther 309:758-768

Fryer RM, Muthukumarana A, Harrison PC, Nodop Mazurek S, Chen RR, Harrington KE, Dinallo RM, Horan JC, Patnaude L, Modis LK, Reinhart GA (2012) The clinically-tested S1P receptor agonists, FTY720 and BAF312, demonstrate subtype-specific bradycardia $\left(\mathrm{S}_{1} \mathrm{P}_{1}\right)$ and hypertension $\left(\mathrm{S}_{1} \mathrm{P}_{3}\right)$ in rat. PLoS One 7: e52985.

Gonzalez-Cabrera PJ, Jo E, Sanna MG, Brown S, Leaf N, Marsolais D, Schaeffer MT, Chapman J, Cameron M, Guerrero M, Roberts E, Rosen H (2008) Full pharmacological efficacy of a novel S1P1 agonist that does not require S1P-like headgroup interactions. Mol Pharmacol 74:1308-1318

Greenwood J, Heasman SJ, Alvarez JI, Prat A, Lyck R, Engelhardt B (2011) Review: leucocyte-endothelial cell crosstalk at the bloodbrain barrier: a prerequisite for successful immune cell entry to the brain. Neuropathol Appl Neurobiol 37:24-39

Huwiler A, Pfeilschifter J (2009) Lipids as targets for novel antiinflammatory therapies. Pharmacol Ther 124:96-112

Huwiler A, Bourquin F, Kotelevets N, Pastukhov O, Capitani G, Grütter MG, Zangemeister-Wittke U (2011) A prokaryotic S1P lyase degrades extracellular S1P in vitro and in vivo: implication for treating hyperproliferative disorders. PLoS One 6: e22436.

Igarashi J, Bernier SG, Michel T (2001) Sphingosine 1-phosphate and activation of endothelial nitric-oxide synthase. Differential regulation of Akt and MAP kinase pathways by EDG and bradykinin receptors in vascular endothelial cells. J Biol Chem 276:1242012426

Imeri F, Fallegger D, Zivkovic A, Enzmann G, Schwalm S, Blankenbach K, Meyer zu Heringdorf D, Homann T, Kleuser B, Pfeilschifter J, Engelhardt B, Stark H, Huwiler A (2014) Novel oxazolo-oxazole derivatives of FTY720 induce lymphopenia and reduce symptoms of experimental autoimmune encephalomyelitis in mice. Neuropharmacology 85C:314-327

Johnson P, Ruffell B (2009) CD44 and its role in inflammation and inflammatory diseases. Inflamm Allergy Drug Targets 8:208-220

Kappos L, Radue EW, O’Connor P, Polman C, Hohlfeld R, Calabresi P, Selmaj K, Agoropoulou C, Leyk M, Zhang-Auberson L, Burtin P, FREEDOMS Study Group (2010) A placebo-controlled trial of oral fingolimod in relapsing multiple sclerosis. N Engl J Med 362:387401

Kim JH, Kim JH, Song WK, Kim JH, Chun JS (2000) Sphingosine 1phosphate activates Erk-1/-2 by transactivating epidermal growth factor receptor in rat-2 cells. IUBMB Life 50:119-124

Kim I, Moon SO, Kim SH, Kim HJ, Koh YS, Koh GY (2001) Vascular endothelial growth factor expression of intercellular adhesion molecule 1 (ICAM-1), vascular cell adhesion molecule 1 (VCAM-1), and $\mathrm{E}$-selectin through nuclear factor-kappa $\mathrm{B}$ activation in endothelial cells. J Biol Chem 276:7614-7620

Lawson C, Wolf S (2009) ICAM-1 signaling in endothelial cells. Pharmacol Rep 61:22-32

Matloubian M, Lo CG, Cinamon G, Lesneski MJ, Xu Y, Brinkmann V, Allende ML, Proia RL, Cyster JG (2004) Lymphocyte egress from thymus and peripheral lymphoid organs is dependent on S1P receptor 1. Nature 427:355-360

Mousa SA (2008) Cell adhesion molecules: potential therapeutics and diagnostic implications. Mol Biotechnol 38:33-40

Müller WA (2011) Mechanisms of leukocyte transendothelial migration. Annu Rev Pathol 6:323-344 
Mutoh T, Chun J (2008) Lysophospholipid activation of G proteincoupled receptors. Subcell Biochem 49:269-297

Osada M, Yatomi Y, Ohmori T, Ikeda H, Ozaki Y (2002) Enhancement of sphingosine 1-phosphate-induced migration of vascular endothelial cells and smooth muscle cells by an EDG-5 antagonist. Biochem Biophys Res Commun 299:483-487

Ponta H, Sherman L, Herrlich PA (2003) CD44: from adhesion molecules to signalling regulators. Nat Rev Mol Cell Biol 4:33-45

Pyne NJ, Waters C, Moughal NA, Sambi BS, Pyne S (2003) Receptor tyrosine kinase-GPCR signal complexes. Biochem Soc Trans 31: $1220-1225$

Rosen H, Stevens RC, Hanson M, Roberts E, Oldstone MB (2013) Sphingosine-1-phosphate and its receptors: structure, signaling, and influence. Annu Rev Biochem 82:637-662

Sanchez T, Estrada-Hernandez T, Paik JH, Wu MT, Venkataraman K, Brinkmann V, Claffey K, Hla T (2003) Phosphorylation and action of the immunomodulator FTY720 inhibits vascular endothelial cell growth factor-induced vascular permeability. J Biol Chem 278: 47281-47290

Sanna MG, Liao J, Jo E, Alfonso C, Ahn MY, Peterson MS, Webb B, Lefebvre S, Chun J, Gray N, Rosen H (2004) Sphingosine 1phosphate $(\mathrm{S} 1 \mathrm{P})$ receptor subtypes $\mathrm{S} 1 \mathrm{P} 1$ and S1P3, respectively, regulate lymphocyte recirculation and heart rate. J Biol Chem 279: 13839-13848

Sanna MG, Wang SK, Gonzalez-Cabrera PJ, Don A, Marsolais D, Matheu MP, Wei SH, Parker I, Jo E, Cheng WC, Cahalan MD, Wong CH, Rosen H (2006) Enhancement of capillary leakage and restoration of lymphocyte egress by a chiral S1P1 antagonist in vivo. Nat Chem Biol 2:434-441

Strub GM, Maceyka M, Hait NC, Milstien S, Spiegel S (2010) Extracellular and intracellular actions of sphingosine-1-phosphate. Adv Exp Med Biol 688:141-155

Theilmeier G, Schmidt C, Herrmann J, Keul P, Schäfers M, Herrgott I, Mersmann J, Larmann J, Hermann S, Stypmann J, Schober O, Hildebrand R, Schulz R, Heusch G, Haude M, von Wnuck LK, Herzog C, Schmitz M, Erbel R, Chun J, Levkau B (2006) Highdensity lipoproteins and their constituent, sphingosine-1-phosphate, directly protect the heart against ischemia/reperfusion injury in vivo via the S1P3 lysophospholipid receptor. Circulation 114:1403-1409

Tölle M, Levkau B, Keul P, Brinkmann V, Giebing G, Schönfelder G, Schäfers M, von Wnuck LK, Jankowski J, Jankowski V, Chun J, Zidek W, Van der Giet M (2005) Immunomodulator FTY720 Induces eNOS-dependent arterial vasodilatation via the lysophospholipid receptor S1P3. Circ Res 96:913-920

Turowski P, Adamson P, Greenwood J (2005) Pharmacological targeting of ICAM-1 signaling in brain endothelial cells: potential for treating neuroinflammation. Cell Mol Neurobiol 25:153-170 van Doorn R, Lopes Pinheiro MA, Kooij G, Lakeman K, van het Hof B, van der Pol SM, Geerts D, van Horssen J, van der Valk P, van der Kam E, Ronken E, Reijerkerk A, de Vries HE (2012) Sphingosine 1-phosphate receptor 5 mediates the immune quiescence of the human brain endothelial barrier. J Neuroinflammation 9:133

Vestweber D (2012) Relevance of endothelial junctions in leukocyte extravasation and vascular permeability. Ann N Y Acad Sci 1257:184192

von Andrian UH, Mackay CR (2000) T-cell function and migration. Two sides of the same coin. N Engl J Med 343:1020-1034

Waters C, Sambi B, Kong KC, Thompson D, Pitson SM, Pyne S, Pyne NJ (2003) Sphingosine 1-phosphate and platelet-derived growth factor (PDGF) act via PDGF beta receptor-sphingosine 1-phosphate receptor complexes in airway smooth muscle cells. J Biol Chem 278: $6282-6290$

Whetzel AM, Bolick DT, Srinivasan S, Macdonald TL, Morris MA, Ley K, Hedrick CC (2006) Sphingosine-1 phosphate prevents monocyte/endothelial interactions in type 1 diabetic NOD mice through activation of the S1P1 receptor. Circ Res 99:731-739

Winkler CW, Foster SC, Matsumoto SG, Preston MA, Xing R, Bebo BF, Banine F, Berny-Lang MA, Itakura A, McCarty OJ, Sherman LS (2012) Hyaluronan anchored to activated CD44 on central nervous system vascular endothelial cells promotes lymphocyte extravasation in experimental autoimmune encephalomyelitis. J Biol Chem 287:33237-33251

Worthylake RA, Burridge K (2001) Leukocyte transendothelial migration: orchestrating the underlying molecular machinery. Curr Opin Cell Biol 13:569-577

Xin C, Ren S, Pfeilschifter J, Huwiler A (2004a) Heterologous desensitization of the sphingosine-1-phosphate receptors by purinoceptor activation in renal mesangial cells. Br J Pharmacol 143:581-589

Xin C, Ren S, Kleuser B, Shabahang S, Eberhardt W, Radeke H, SchäferKorting M, Pfeilschifter J, Huwiler A (2004b) Sphingosine 1phosphate cross-activates the Smad signaling cascade and mimics transforming growth factor- $\beta$-induced cell responses. J Biol Chem 279:35255-35262

Xin C, Ren S, Eberhardt W, Pfeilschifter J, Huwiler A (2006) The immunomodulator FTY720 and its phosphorylated derivative activate the Smad signalling cascade and upregulate connective tissue growth factor and collagen type IV expression in renal mesangial cells. $\mathrm{Br} \mathrm{J}$ Pharmacol 147:164-174

Zemann B, Kinzel B, Müller M, Reuschel R, Mechtcheriakova D, Urtz N, Bornancin F, Baumruker T, Billich A (2006) Sphingosine kinase type 2 is essential for lymphopenia induced by the immunomodulatory drug FTY720. Blood 107:1454-1458 